\title{
Diet, Feeding Rate, Growth, Mortality, and Production of Juvenile Steelhead in a Lake Michigan Tributary
}

\author{
Neal A. Godby JR. \\ Michigan Department of Natural Resources, Fisheries Division, \\ 1732 M-32 West, Gaylord, Michigan 49735, USA \\ EDWARD S. RUTHERFORD* \\ Institute for Fisheries Research, School of Natural Resources and Environment, University of Michigan, \\ 218 Museum Annex Building, 1109 North University, Ann Arbor, Michigan 48109-1084, USA

\section{DORAN M. MASON} \\ National Oceanic and Atmospheric Administration, Great Lakes Environmental Research Laboratory, \\ 2205 Commonwealth Boulevard, Ann Arbor, Michigan 48105, USA

\begin{abstract}
Steelhead Oncorhynchus mykiss support valuable sport fisheries in the Great Lakes but are largely sustained by stocking. In many Great Lakes tributaries, steelhead spawning and nursery habitats are limited by hydropower dams, and natural recruitment may be supplemented by habitats in adjacent coldwater creeks. In 1998-2001, we investigated the potential for natural production of steelhead in the Muskegon River, Michigan, a tributary to Lake Michigan, through analysis of parr diet categories, consumption, growth, survival, and production in the main-stem Muskegon River and in Bigelow Creek. We used electrofishing surveys to estimate parr growth and survival from changes in fish weight and density over time. We estimated diet from gut content analysis and consumption from bioenergetics model analysis. Average fall density of parr in Bigelow Creek was 20-fold higher than in the Muskegon River. Average summer daily mortality rate of parr in the Muskegon River was nearly threefold higher than in Bigelow Creek. Overwinter mortality rates of parr were low in both habitats. Few yearling and older parr were present in the Muskegon River relative to Bigelow Creek. Age-0 parr primarily consumed benthic invertebrates. Macroinvertebrate prey densities were sufficient to support high parr growth rates in both rivers. Parr grew at similar rates but consumed $84 \%$ more per day in the Muskegon River, which had higher water temperatures than Bigelow Creek. Age-0 production was fivefold higher in Bigelow Creek than in the Muskegon River. High mortalities of parr in the Muskegon River were correlated with summer water temperatures exceeding $21^{\circ} \mathrm{C}$. Average summer temperatures in Bigelow Creek $\left(17^{\circ} \mathrm{C}\right)$ were optimal for parr survival. Our results were consistent with data from other Great Lakes tributaries and suggest that small tributary creek habitats contribute disproportionately to steelhead recruitment from large impounded watersheds by providing optimal thermal refugia for parr during summer.
\end{abstract}

Steelhead Oncorhynchus mykiss (adfluvial rainbow trout) are an important component of the Great Lakes sport fishery, which is valued at approximately US $\$ 1 \times$ $10^{9}$ per year (Talheim 1987). In Lake Michigan, approximately $20-30 \%$ of adult steelhead in the sport fishery are wild or originate from natural reproduction (Rand et al. 1993). Rivers in the northwest Lower Peninsula of Michigan provide abundant potential nursery habitat for steelhead, but nearly all are impounded and many experience abnormal temperature and flow regimes. Some of the impounded rivers in the region have recently changed from peaking operations, where water is held back and released twice daily, to run-of-the-river flow regimes, which mimic

* Corresponding author: edwardr@umich.edu

Received March 6, 2006; accepted September 7, 2006 Published online April 26, 2007 natural flow cycles. The stabilization of flows is believed to have improved nursery habitat for salmonids, but the impacts are largely unknown (Woldt and Rutherford 2002). Top-draw dams can increase the mean temperature and decrease the diel temperature variation in the tailrace nursery habitats, increasing metabolic rates of resident fishes (Petts 1984) and increasing consumption rates of predators.

The factors limiting steelhead growth, mortality, and production in many Great Lakes tributaries are poorly understood. Previous studies on Great Lakes steelhead have focused on the effects of temperature and flow stability on parr density, size and smolt production, but largely ignored the potential role of biotic factors, primarily density and diet. Seelbach (1987, 1993) demonstrated that in tributaries where summer temperatures are optimal for steelhead growth and survival, steelhead production may be limited more by severity of winter temperatures than by maximum summer 


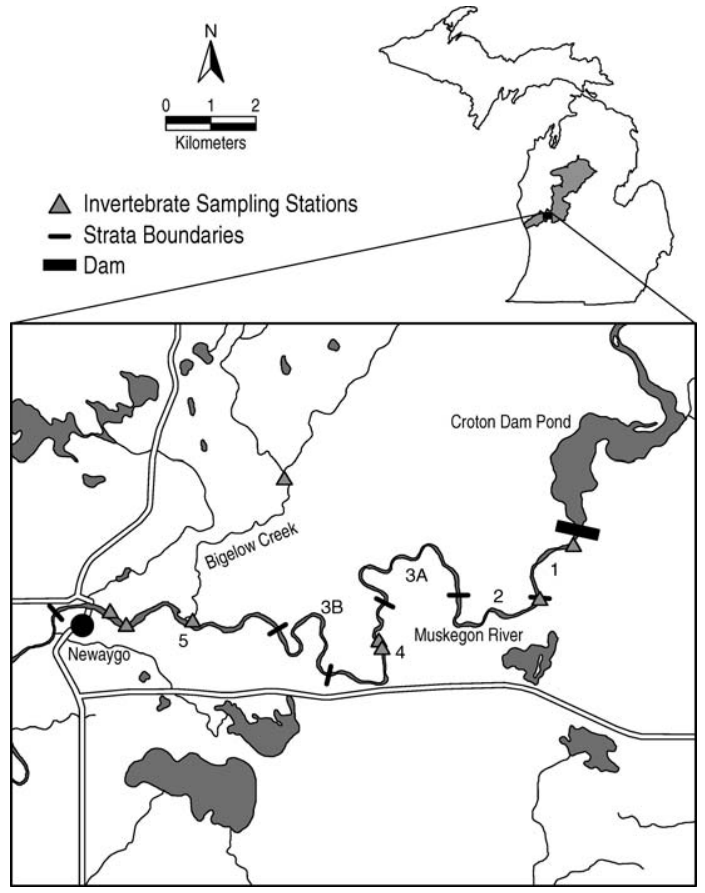

FIGURE 1.-Map of the study area in the Muskegon River and Bigelow Creek, Michigan, showing locations of five study strata and invertebrate sampling stations.

temperatures. In tributaries with suboptimal thermal regimes, such as the impounded Manistee River (Woldt and Rutherford 2002) and free-flowing Betsie River tributaries (Newcomb and Coon 1997), warm summer water temperatures are coincident with high mortality of age-0 parr. However, temperature may interact with factors such as macroinvertebrate prey density and parr size to influence steelhead ration, growth, and survival through density-dependent processes (e.g., Chapman 1966; Allen 1969). How biotic factors such as macroinvertebrate prey density and parr density interact with physical factors to affect parr survival and growth in Great Lakes tributaries is unknown.

This study was initiated to investigate factors regulating dynamics of age- 0 steelhead production in a large impounded river and a connecting tributary creek characteristic of many Great Lakes watersheds. Specific objectives of the study were to quantify and compare factors influencing diet, consumption, growth, mortality, and production of age- 0 parr between the impounded Muskegon River and Bigelow Creek, an unimpounded coldwater tributary of the Muskegon River. A bioenergetics model (Hanson et al. 1997) was used to evaluate the relative effects of temperature and prey composition on steelhead consumption and growth in each river. To support conclusions reached
TABLE 1.-Average ( $\pm 2 \mathrm{SE})$ river substrate composition, physical-chemical characteristics, and macroinvertebrate prey densities within sampled habitats of the Muskegon River and Bigelow Creek, Michigan, August 1998. River habitat characteristics were measured at randomly located shoreline sites within strata in the Muskegon River and at fixed sites in Bigelow Creek. Macroinvertebrate densities were measured at nearshore riffle habitats in both rivers. Dissolved oxygen was measured during 2002.

\begin{tabular}{lcc}
\hline \multicolumn{1}{c}{$\begin{array}{c}\text { Habitat } \\
\text { variable }\end{array}$} & $\begin{array}{c}\text { Muskegon } \\
\text { River }\end{array}$ & $\begin{array}{c}\text { Bigelow } \\
\text { Creek }\end{array}$ \\
\hline Dissolved oxygen $(\mathrm{mg} / \mathrm{L})$ & $7.9 \pm 0.2$ & 9.4 \\
$\mathrm{pH}$ & $7.9 \pm 0.05$ & $8.3 \pm 0.2$ \\
Conductivity $(\mu \mathrm{S} / \mathrm{cm})$ & $330 \pm 5$ & $280 \pm 25$ \\
Percent gravel plus cobble & $55 \pm 7$ & $35 \pm 37$ \\
Percent woody debris & $5.9 \pm 2.6$ & $11.7 \pm 9.9$ \\
$\begin{array}{l}\text { Flow velocity }(\mathrm{m} / \mathrm{s}) \\
\text { Temperature }\left({ }^{\circ} \mathrm{C}\right)\end{array}$ & $0.23 \pm 0.05$ & $0.58 \pm 0.36$ \\
$\begin{array}{l}\text { Total macroinvertabrate } \\
\text { density }\left(\text { number/m }{ }^{2}\right)\end{array}$ & $21.9 \pm 0.3$ & $18.0 \pm 0.7$ \\
$\begin{array}{c}\text { Hydropsychidae density } \\
\left(\text { number/m }{ }^{2}\right)\end{array}$ & $16,561 \pm 6,799$ & $34,506 \pm 14,982$ \\
$\begin{array}{c}\text { Chironomidae density } \\
\left(\text { number } / \mathrm{m}^{2}\right)\end{array}$ & $1,723 \pm 763$ & $1,813 \pm 1444$ \\
\hline
\end{tabular}

on the Muskegon River and Bigelow Creek, we conducted a detailed analysis of factors influencing age-0 steelhead parr dynamics in several other Great Lakes tributaries.

\section{Study Area}

The Muskegon River is one of the largest tributaries to Lake Michigan (Figure 1), possessing a length of $341 \mathrm{~km}$ and a contributing watershed of over 5,900 $\mathrm{km}^{2}$ (O'Neal 1997). Land development in the watershed is moderate, ranging from $16.7 \%$ to $34.0 \%$ of the main-stem area, and is devoted mostly to agriculture. Watershed soils are primarily permeable, glacial outwash and end moraine materials (sand, gravel, coarse till). The river has four major impoundments: Croton, Hardy, Rogers, and Reedsburg. Our study reach covered the primary salmonid spawning and nursery areas, and extended approximately $22.5 \mathrm{~km}$ from Croton Dam downriver to Newaygo, Michigan, and averaged $65 \mathrm{~m}$ in width. The channel morphology of the study area consists of predominantly runs interrupted by occasional riffles. The study area has a moderate gradient of $2-5 \mathrm{~m} / \mathrm{km}$; flow velocities range from 0.5 to $1.0 \mathrm{~m} / \mathrm{s}$, and the mixed substrate is composed primarily of gravel, cobble, and sand, and little organic silt or boulder (Table 1). Mean annual flow of the river's main stem at Croton Dam is approximately $62 \mathrm{~m}^{3} / \mathrm{s}$. Croton Dam serves as the upstream barrier to migration by adfluvial fishes, including steelhead and Chinook salmon O. tshawytscha. At the time of the study, this reach of the Muskegon River was stocked by the Michigan 
TABLE 2.-Strata location and substrate description in the Muskegon River (Michigan) study area (Ichthyological Associates 1991).

\begin{tabular}{|c|c|c|}
\hline Stratum & $\begin{array}{l}\text { Location (m downstream } \\
\text { of Croton Dam) }\end{array}$ & Substrate-habitat \\
\hline 1 & $305-1,829$ & Gravel riffle spawning habitat \\
\hline 2 & $1,829-4,267$ & Spawning habitat with run holding habitat \\
\hline 3 & $4,267-8,534,11,582-15,240$ & Run-pool with some high banks \\
\hline 4 & $8,534-11,582$ & Deep and shallow runs with spawning gravel \\
\hline 5 & $18,288-21,031$ & $\begin{array}{l}\text { Higher-gradient reach with instream cover } \\
\text { provided by man-made log-rock cribs }\end{array}$ \\
\hline
\end{tabular}

Department of Natural Resources (MDNR) with brown trout Salmo trutta (50,000 fish/year), rainbow trout (domestic strain, 75,000 fish/year), steelhead $(50,000$ smolts/year), and Chinook salmon (250,000 smolts/ year). The river's main stem contributes the highest percentage of naturally produced Chinook salmon of any Lake Michigan tributary, averaging 100,000500,000 presmolts per year (Carl 1982; O'Neal 1997). Harvest of spawning steelhead and Chinook salmon from the main-stem Muskegon River averages over 20,000 adults per year for each species.

Sampling sites also were located in Bigelow Creek, a small, free-flowing coldwater tributary of the Muskegon River, which enters the main stem of the Muskegon River just upstream of Newaygo. Bigelow Creek is $12.1 \mathrm{~km}$ long, has an average width of $5.3 \mathrm{~m}$, and has a contributing watershed of $44.9 \mathrm{~km}^{2}$. Stream gradient is moderate; the stream exhibits a typical riffle-pool-run sequence, and substrate is composed of gravel and sand (Table 1). Recent flow and discharge measurements in Bigelow Creek indicate flow velocities of $0.5-1.0 \mathrm{~m} / \mathrm{s}$, average discharges between 0.3 and $0.6 \mathrm{~m}^{3} / \mathrm{s}$, and a maximum discharge of $1.2 \mathrm{~m}^{3} / \mathrm{s}(\mathrm{P}$. Richards, University of Michigan, Ann Arbor, unpublished data). Bigelow Creek is not stocked by the MDNR.

\section{Methods}

Sampling design.-Population vital rates (growth, mortality), production, and habitat characteristics of age-0 steelhead were estimated from samples collected using a stratified random sampling design. Population characteristics and habitat characteristics also were estimated for parr at two sites in Bigelow Creek (Figure 1). In the Muskegon River, five strata (Table 2) were delineated for the study reach between Croton Dam and Newaygo, based on a previous multivariate analysis (principal components analysis) of riparian and instream substrate conducted in 1989 (Ichthyological Associates 1991). Each stratum was divided into 100$\mathrm{m}$ shoreline segments, and shoreline sites were randomly selected from the five strata. In 1998-1999, the number of sites sampled was as follows: 11 sites from stratum 1; 3 from stratum 2; 5 from stratum 3; 4 from stratum 4; and 16 from stratum 5 . The number of sites sampled was revised slightly in 2000 and 2001 based on results from 1998. The new sample allocation for 2000-2001 was 12 sites from stratum 1; 9 from stratum 2; 4 from stratum 3; 2 from stratum 4; and 4 from stratum 5 . Within each year, the number of sampled sites was constant in each stratum. The original number of sites chosen for each stratum was determined based on the dominant substrate type in the stratum (Table 2); optimal spawning sites for salmonids received more weight. The total number of sites sampled was determined from (1) known variances around steelhead density in similar habitats in other Lake Michigan tributaries (Woldt and Rutherford 2002), (2) the desire to estimate the population density within a specified confidence interval (CI) of $30 \%$, and (3) the necessity of completing the survey within a reasonably short time period (7-9 d).

Instream habitat.-Instream habitat data were collected at each of the sample sites on the Muskegon River and Bigelow Creek in 1998 and 2000. A 1-m² quadrat was randomly placed at the beginning, middle, and end of each site. Temperature $\left({ }^{\circ} \mathrm{C}\right.$; digital thermometer), conductivity ( $\mu \mathrm{S} / \mathrm{cm}$; Hach conductivity meter), $\mathrm{pH}$ (Hach $\mathrm{pH}$ meter), depth $(\mathrm{m})$, velocity at 0.6 $\times$ depth (m/s; Swoffer 2100 flowmeter), substrate composition (visual estimation), percentage bottom cover of vegetation (visual estimation), percentage bottom cover of woody debris (visual estimation), and percentage shaded area (visual estimation) were measured within each quadrat. In 2001, only velocity and temperature measurements were made at sampling sites. Daily discharge data for the Muskegon River were obtained from the U.S. Geological Survey station below Croton Dam.

Temperature also was monitored continuously (2-h intervals) in 1998 and 2000 at two sites in the Muskegon River main stem and two sites in Bigelow Creek using submersible data recorders (Hobo and Stowaway). Temperature information was downloaded from each recorder about every 4 months, and then the recorders were re-deployed. In most cases, mean daily 
temperature, temperature change (daily maximum daily minimum), and maximum temperature were calculated at sites of interest.

Density and survival.-Density of age-0 steelhead parr was estimated from samples collected at unblocked shoreline sites during 4 years: August and October 1998; March 1999 (when the cohort had become yearlings); and July and October 2000 and 2001. Each 300- $\mathrm{m}^{2}$ site was sampled using a 250-300V DC stream electrofishing unit. Parr density was estimated at each site using the Moran-Zippin two-pass depletion method (Everhart and Youngs 1981); additional passes were made at some sites to achieve depletion. The site-specific estimate of parr density (number/ha) was expanded to mean stratum density and a population mean density using a stratified random sampling equation (Scheaffer et al. 1996). The pass depletion method was chosen over markrecapture techniques because of problems associated with marking sufficient numbers of individuals smaller than $5 \mathrm{~cm}$. Efficiency of the pass depletion method (calculated as proportion of total estimate sampled by the first pass) averaged $67-70 \%$ for age- 0 steelhead over all surveys. There was no significant difference in efficiency among strata with the main stem, or between Bigelow Creek and the main stem (Kruskal-Wallis test: $\left.\chi^{2}=2.98, P>0.70\right)$.

Percent survival $(S)$ of steelhead parr was calculated as $S=N_{t+1} / N_{t} \times 100$, where $N_{t}$ and $N_{t+1}$ are densities at times $t$ and $t+1$, respectively. Instantaneous daily mortality rate $(Z)$ of steelhead parr was calculated as $\log _{e}(S) / d$, where $d$ is the number of days between samples. Changes in parr density from summer to fall and from fall to spring represent loss rates that include immigration and emigration of individuals as well as actual mortality. However, we are confident that emigration and immigration rates were low between summer and fall survey periods based on studies of movement and density of age-0 parr elsewhere in the Great Lakes and western United States (e.g., Johnson and Kucera 1985; Sheppard and Johnson 1985; Woldt and Rutherford 2002), and we therefore have chosen to represent density changes as mortality.

Growth.-Growth was estimated from changes in length and weight of the cohort between sampling periods. Total length (TL, cm) and wet weight (g) were measured for samples of up to 30 fish at each site. The instantaneous daily rate of growth in weight $(G)$ was estimated by $G=\log _{e}\left(W_{t}-W_{t+1}\right) / d$, where $W_{t}$ and $W_{t+1}$ are the mean weights at times $t$ and $t+1$, respectively, and $d$ is the number of days between samples.

Production.-Production estimates were made using the Allen (1971) method and also by calculating a $G: Z$ ratio. The $G: Z$ ratio is a relative index of production and is calculated by dividing the instantaneous daily growth rate $(G)$ by $Z$. The Allen (1971) method involves calculation of production from the relationship between the increase in cohort biomass and decline in cohort density over time. $\log _{e}$ transformed steelhead density $(y)$ was regressed against average wet weight of individuals $(x)$, and production (area under these curves) was calculated using the following formula (Pitcher and Hart 1996):

$$
P=\int_{w_{0}}^{w_{t}} D_{i} d w
$$

where $P$ is production, $w_{0}$ is average weight at time 0 , $w_{t}$ is average weight at time $t, D_{i}$ is density at time $i$, and $d w$ is the derivative of average weight. The area under the fitted curve of cohort biomass and population size represented total production in grams per hectare, which was then converted to grams per square meter.

Diet and ration.-Six sampling sites were selected for diet studies in the Muskegon River in the reach between Croton Dam and Newaygo (Figure 1) to coincide with the invertebrate sampling sites used in a companion study (Godby 2000). These sites corresponded with riffle sites selected for parr abundance estimates. Two sites per stratum were selected for strata 1, 4, and 5. Two sites also were selected for Bigelow Creek.

Steelhead used for stomach content analysis were collected as age-0 parr in August and October 1998 and as age-1 parr in May 1999 to coincide with major feeding and growing seasons (summer, fall, and spring). Fish were collected near invertebrate sampling stations described by Godby (2000). Number of steelhead sampled for diet decreased from summer to fall and from fall to spring, as not enough steelhead were collected to keep diet sample sizes equal due to the high mortality of age- 0 parr. To supplement sample sizes of wild steelhead in the spring, newly stocked hatchery fish were collected for diet analysis. These recently stocked fish had been in the river for at least 2 weeks and had been eating natural food. Although some studies have demonstrated that hatchery salmonids behave and forage differently than wild salmonids when first released in streams $(<3 \mathrm{~d})$, other studies indicate no differences in diet composition after a few weeks (e.g., Johnson 1981; Johnson et al. 1996). Our comparison of diets of hatchery and wild yearlings indicated no significant differences in diet composition.

Approximately 10 age-0 steelhead were collected for diet analysis at each site and date by means of a stream or backpack electrofisher, a seine, or both. The parr were preserved in $10 \%$ formalin and were later transferred to a $70 \%$ ethanol solution for subsequent 
analysis. In the laboratory, the stomachs, along with the intestines, esophagus, and gill arches, were removed from the fish and preserved in a $70 \%$ ethanol solution for later analysis of the stomach contents. Preserved fish were weighed before removal of the stomachs.

Stomach contents were analyzed in the laboratory by weighing the filled stomach, removing the contents through an incision, and then weighing the empty stomach to estimate total wet weight of the contents. Stomach contents were identified to the lowest taxonomic level that their condition would allow (usually order or family). Dry weights of individual prey items were based on length to biomass conversions (Johnston and Cunjak 1999) calculated from invertebrate samples taken during the same time period, and were converted to wet weights using wet weight : dry weight conversion ratios (Hanson et al. 1997).

We used the Wisconsin Fish Bioenergetics 3.0 model (Hanson et al. 1997) to estimate average daily ration of age- 0 steelhead parr in the Muskegon River and Bigelow Creek during summer and fall of 1998, 2000, and 2001. The model permits estimation of daily ration from inputs of water temperature, predator start and end weights, prey taxa proportions, and caloric densities. We assumed that parr diet composition was constant among years. We entered diet proportions of prey items, based on wet weight determined from 1998 and 1999 samples, into the model to estimate ration and consumption in each year. Other required values, such as water temperature, were measured using continuous data recorders (Hobo or Stowaway) or were collected on site using thermometers, while prey energy densities were obtained from the software manual (Hanson et al. 1997). We used the steelhead model parameters for consumption (proportion of maximum consumption, $\left.p\left[C_{\text {max }}\right]\right)$ and respiration determined by Railsback and Rose (1999). Other bioenergetics model parameters were from Rand et al. (1993). Average daily ration was estimated for each year for July-October or AugustOctober using the model to fit the parameters to the end weight observed in the field. Values for daily water temperatures for the Muskegon River and Bigelow Creek were interpolated between observations made during the summer and fall of 1998 and 2001 and were recorded from the continuous data loggers in 2000.

Statistical analyses.-Parametric tests were used to compare differences in mean parr density, vital rates, production, and consumption among rivers or years where samples were normally distributed and had equal variances. Parr density, length, and weight were averaged over all sites within strata (Scheaffer et al. 1996) and were then combined using a weighted approach for Muskegon River or Bigelow Creek estimates (Scheaffer et al. 1996). The annual point estimates of survival, growth, instantaneous mortality, consumption, and production for each year were averaged for each river. Paired comparisons of vital rates and density between the Muskegon River and Bigelow Creek were made using two-sample $t$-tests. The nonparametric Wilcoxon rank test was used in comparisons when assumptions of normality and heteroscedasticity were not met. Confidence intervals (95\% CI) were calculated for point estimates where possible.

Environmental factors and steelhead dynamics.Correlations among parr density, consumption, and vital rates and environmental variables (e.g., temperature, river discharge) were tested using the nonparametric Spearman's rank correlation coefficient $\left(r_{s}\right)$ for the 1998-2001 data from the Muskegon River and Bigelow Creek. These correlations also were re-run using a larger data set of samples from other Lake Michigan tributaries (Carl 1983; Newcomb and Coon 1997; Woldt and Rutherford 2002; E.S.R., unpublished data) to expand relationships established from the smaller data set. Relationships between density, growth, or mortality of steelhead parr and selected environmental variables were tested using a forwardentry stepwise regression. All statistical tests were performed and all regression models were fit using JMP 4.0 software. Results were considered statistically significant at a significance level $\alpha$ of 0.05 or if the $95 \%$ CIs did not overlap.

\section{Habitat}

\section{Results}

Instream and riparian habitat characteristics differed between the Muskegon River main stem and Bigelow Creek. Average summer temperatures in the Muskegon River were higher in summer and declined more slowly than in Bigelow Creek in each year. Average daily temperatures in the Muskegon River ranged from $21.0^{\circ} \mathrm{C}$ to $23.3^{\circ} \mathrm{C}$ in July-August and declined to 11.0 $14.4^{\circ} \mathrm{C}$ by October (Figure 2; Table 3). Over the same time period, temperatures in Bigelow Creek declined from $14.4-18.0^{\circ} \mathrm{C}$ in July-August to $8.3-10.0^{\circ} \mathrm{C}$ in October. Average July water temperatures were higher in both streams in 2001 than in 2000 (Table 3). In the Muskegon River, cumulative river discharge for the March-June period (hatching through the early parr stage) was lowest in $2000\left(6,557 \mathrm{~m}^{3} / \mathrm{s}\right)$ and highest in $2001\left(8,994 \mathrm{~m}^{3} / \mathrm{s}\right)$.

During summer and fall survey periods, average velocity at shoreline sites along the Muskegon River was $0.23 \mathrm{~m} / \mathrm{s}$ and ranged from 0.09 to $0.45 \mathrm{~m} / \mathrm{s}$. Velocities were highest in strata 2 and 5 and lowest in stratum 4. Water chemistry measurements taken in 1998 and 2000 showed that conductivity values at 


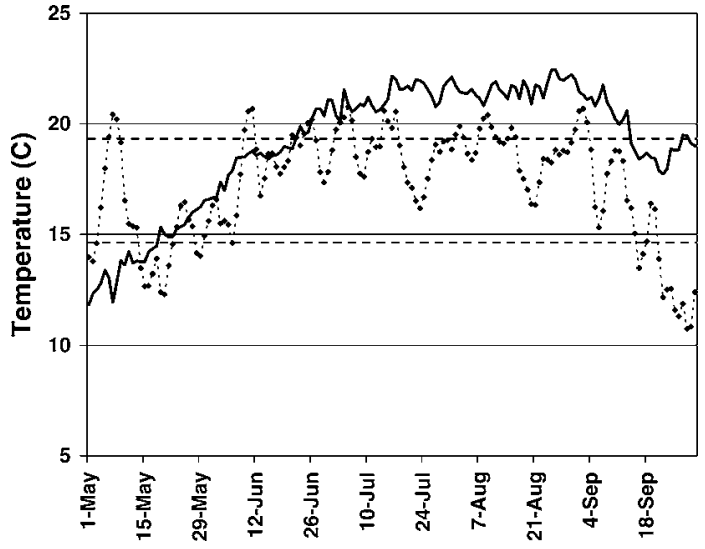

Figure 2.-Mean daily temperature in the Muskegon River (solid line) and Bigelow Creek (dashed line with $\bullet$ ), Michigan, during 2000. Horizontal dashed lines demarcate the range of optimal temperatures for growth and survival of age-0 steelhead (Hokanson et al. 1977).

survey sites averaged $330 \mu \mathrm{S} / \mathrm{cm}$ (range $=290-360 \mu \mathrm{S} /$ $\mathrm{cm}$ ), $\mathrm{pH}$ averaged 7.9 (range $=7.6-8.2$ ), and dissolved oxygen (measured in 2002) averaged $7.2 \mathrm{mg} / \mathrm{L}$ (range $=5.6-8.7 \mathrm{mg} / \mathrm{L}$ ). Temperature, $\mathrm{pH}$, conductivity, and dissolved oxygen generally increased with distance downstream of Croton Dam. Muskegon River shoreline sites had variable but low amounts of woody debris and little shade provided by riparian vegetation. Bottom substrate composition was coarse, and gravelsand or gravel-cobble composition was most common (Table 1). In contrast, sites in Bigelow Creek had higher flow velocities (mean $=0.7 \mathrm{~m} / \mathrm{s}$, range $=0.4-1.0$ $\mathrm{m} / \mathrm{s})$, dissolved oxygen values $(9.4 \mathrm{mg} / \mathrm{L})$, and $\mathrm{pH}$ values (mean $\mathrm{pH}=8.4$ ) but lower mean conductivity values $(280 \mu \mathrm{S} / \mathrm{cm})$. The narrow stream was shaded by heavy riparian cover, had a predominantly gravel-sand substrate, and contained abundant woody debris (Table 1).

\section{Density}

Mean densities of age-0 steelhead parr were significantly lower in the Muskegon River than in Bigelow Creek in each year during all sampling periods $(t=5.01, \mathrm{df}=4, P<0.001)$. Density in the Muskegon River declined from an average of 2,427 $\pm 1,298$ parr/ ha (mean $\pm 2 \mathrm{SE}$ ) in July-August to $122 \pm 118$ parr/ ha by October (mean of values reported in Table 3). Average parr density was 2.8-fold higher in Bigelow Creek than in the Muskegon River in July-August and 20 -fold higher by October. Mean parr density measured in March 1999 was nearly 10-fold higher in Bigelow Creek $(517 \pm 517$ parr/ha) than in the Muskegon River (67 \pm 30 parr/ha) (Table 3$)$. Spatial trends in parr density were relatively consistent across years. In the Muskegon River, parr density was generally higher at strata 1,2 , and 5 (Table 4); the site near the mouth of Bigelow Creek tended to have the highest densities for the river. There were no significant annual differences in summer or fall density of steelhead parr in Bigelow Creek or summer density in the Muskegon River. Mean fall density of parr in the Muskegon River declined steadily from 1998 to 2001 (Kruskal-Wallis test: $\chi^{2}=35.09, P<0.001, \mathrm{df}=2$ ).

\section{Mortality}

Survival of steelhead parr during summer was lower in the Muskegon River than in Bigelow Creek, but not significantly so $(t=2.636$, $\mathrm{df}=4, P<0.06)$. Parr survival from August to October was twice as high in Bigelow Creek as in the Muskegon River $(S=0.36$ versus 0.17) during 1998, and survival was 9-25-fold higher in Bigelow Creek during 2000 and 2001 (Table 5). Overwinter survival rates measured during 19981999 were similar in both rivers. Winter survival was higher than summer survival in the Muskegon River but was lower than summer survival in Bigelow Creek. Instantaneous daily mortality rate of parr during summer was significantly higher in the Muskegon

TABLE 3.-Average $( \pm 95 \% \mathrm{CI})$ population density (fish/ha) of age- 0 steelhead parr and average survey water temperature $\left({ }^{\circ} \mathrm{C}\right)$ in the Muskegon River and Bigelow Creek, Michigan, 1998-2001. Estimates are based on pass depletion techniques using a DC electrofisher. Number of sites sampled was constant within years for each river but decreased for Muskegon River from 39 sites in 1998-1999 to 33 sites in 2000-2001. Number of sites in Bigelow Creek was constant $(n=2)$ across seasons and years.

\begin{tabular}{lcccccr}
\hline & & \multicolumn{2}{c}{ Muskegon River } & & \multicolumn{2}{c}{ Bigelow Creek } \\
\cline { 3 - 4 } \cline { 6 - 6 } Year & Month & Density & Temperature & & Density & Temperature \\
\hline \multirow{2}{*}{1998} & Aug & $1,334 \pm 272$ & 21.8 & & $6,819 \pm 13,638$ & 17.1 \\
& Oct & $217 \pm 50$ & 14.4 & & $2,456 \pm 4,823$ & 8.7 \\
1999 & Mar & $67 \pm 30$ & 2.1 & & $517 \pm 517$ & 2.7 \\
2000 & Jul & $3,581 \pm 975$ & 21.0 & & $8,150 \pm 4,790$ & 14.4 \\
& Oct & $136 \pm 30$ & 11.8 & & $2,934 \pm 1,011$ & 8.8 \\
2001 & Jul & $2,366 \pm 468$ & 23.0 & & $5,850 \pm 2,052$ & 18.0 \\
& Oct & $13 \pm 4$ & 11.0 & & $2,504 \pm 889$ & 10.0 \\
\hline
\end{tabular}


TABLE 4.-Average ( \pm 2 SE) strata density (fish/ha) of age- 0 steelhead parr in the Muskegon River, Michigan. Number of sites sampled were constant within strata across seasons but changed from 1998-1999 (stratum 1, $n=11$; stratum 2, $n=3$; stratum $3, n=5$; stratum $4, n=4$; stratum $5, n=16$ ) to 2000 2001 (stratum 1, $n=12$; stratum 2, $n=9$; stratum 3, $n=4$; stratum $4, n=2$; stratum $5, n=4$ ).

\begin{tabular}{cccr}
\hline $\begin{array}{l}\text { Year and } \\
\text { stratum }\end{array}$ & Jul-Aug & Oct & Mar (1999) \\
\hline 1998 & & & \\
1 & $2,779 \pm 706$ & $571 \pm 247$ & $52 \pm 59$ \\
2 & $2,576 \pm 880$ & $695 \pm 252$ & $378 \pm 210$ \\
3 & $891 \pm 392$ & $108 \pm 62$ & $7 \pm 7$ \\
4 & $1,129 \pm 901$ & $83 \pm 47$ & $25 \pm 28$ \\
5 & $942 \pm 136$ & $58 \pm 27$ & $15 \pm 6$ \\
2000 & & & \\
1 & $3,281 \pm 2,232$ & $62 \pm 15$ & \\
2 & $4,053 \pm 825$ & $299 \pm 101$ & \\
3 & $2,437 \pm 2,257$ & $38 \pm 43$ & \\
4 & $903 \pm 2,257$ & $53 \pm 40$ & \\
5 & $5,901 \pm 2,428$ & $93 \pm 59$ & \\
2001 & & & \\
1 & $1,111 \pm 311$ & 0 & \\
2 & $4,276 \pm 1,402$ & $11 \pm 6$ & \\
3 & $411 \pm 239$ & 0 & \\
4 & $1,853 \pm 2,932$ & 0 & \\
5 & $4,173 \pm 1,358$ & $75 \pm 62$ & \\
& & & \\
\hline
\end{tabular}

River than in Bigelow Creek $(t=2.919$, df $=4, P<$ 0.05) (Table 5). Mortality of parr in the Muskegon River increased greatly in 2001 from previous years.

\section{Growth}

Although length, weight, and growth rate tended to be higher in the Muskegon River than in Bigelow Creek, they were not significantly higher. Mean length and weight of parr in summer and fall were similar in the Muskegon River and Bigelow Creek (Figures 3, 4).
Average instantaneous daily growth rate of parr did not differ between the Muskegon River $(G=0.019 \pm$ $0.004)$ and Bigelow Creek $(G=0.012 \pm 0.004)$ (Table 5).

\section{Production}

Average production rates of age- 0 steelhead parr in Bigelow Creek were high but not significantly greater than those in the Muskegon River. The average $G: Z$ ratio of steelhead parr from July-August to October was $1.20 \pm 0.46$ for Bigelow Creek and $0.56 \pm 0.23$ for the Muskegon River $(t=2.484$, df $=4, P<0.07)$. The Allen (1971) estimate of production from JulyAugust to October averaged $0.39 \pm 0.27 \mathrm{~g} / \mathrm{m}^{2}$ for the Muskegon River and $2.00 \pm 1.18 \mathrm{~g} / \mathrm{m}^{2}$ for Bigelow Creek $(t=2.644$, df $=4, P<0.06)$.

Diet

Age-0 steelhead parr consumed a wide variety of prey types in both rivers. Hydropsychid caddisflies, chironomid midges, and ephemerellid mayflies were the most frequently observed prey items. In the Muskegon River, amphipods and trichopterans were the predominant prey (\% wet weight) of steelhead parr in August ( $N=49$ nonempty stomachs), whereas hydropsychids and salmon eggs were the primary prey in October ( $N=33$ nonempty stomachs) (Table 6). Mayflies, especially ephemerellids, and dipterans became important prey taxa in May $1999(N=44$ nonempty stomachs) (Table 6). The zooplankton taxa Cladocera and Bythotrephes cederstroemi also were found in stomachs of parr collected at Muskegon River sites closest to Croton Dam, primarily during the summer and fall sampling periods.

TABLE 5.-Vital rates and production of age-0 steelhead parr in the Muskegon River and Bigelow Creek, Michigan, during summer (Jul-Oct) and winter (Oct-Mar) of 1998, 2000, and 2001. Vital rates are instantaneous daily rate of growth in weight $(G)$, fraction surviving $(S)$, instantaneous daily mortality rate $(Z), G: Z$ ratio, and production $\left(\mathrm{g} / \mathrm{m}^{2}\right)$. Average values were unweighted means of annual values. Values of $S$ and $Z$ were derived from density estimates in Table 3. In the Muskegon River each year, age- 0 growth rates were derived from estimated weights of more than 500 fish in summer, more than 100 fish in fall (except in 2001, $n=11$ ), and more than 60 fish in spring. Weights in Bigelow Creek were estimated from approximately 30 fish in each sampling period.

\begin{tabular}{|c|c|c|c|c|c|c|c|c|c|}
\hline \multirow[b]{2}{*}{ Year } & \multicolumn{5}{|c|}{ Jul-Oct or Aug-Oct } & \multicolumn{4}{|c|}{ Oct-Mar } \\
\hline & $G$ & $S$ & $Z$ & $G: Z$ & Production & $G$ & $S$ & $Z$ & $G: Z$ \\
\hline \multicolumn{10}{|c|}{ Muskegon River } \\
\hline 1998 & 0.017 & 0.163 & 0.025 & 0.68 & 0.40 & 0.002 & 0.31 & 0.009 & 0.22 \\
\hline 2000 & 0.022 & 0.038 & 0.033 & 0.67 & 0.62 & & & & \\
\hline 2001 & 0.017 & 0.006 & 0.053 & 0.33 & 0.15 & & & & \\
\hline Average & 0.019 & 0.070 & 0.037 & 0.56 & 0.39 & & & & \\
\hline \multicolumn{10}{|c|}{ Bigelow Creek } \\
\hline 1998 & 0.010 & 0.36 & 0.012 & 0.86 & 1.45 & 0.003 & 0.21 & 0.012 & 0.25 \\
\hline 2000 & 0.016 & 0.36 & 0.010 & 1.64 & 3.18 & & & & \\
\hline 2001 & 0.011 & 0.15 & 0.010 & 1.12 & 1.36 & & & & \\
\hline Average & 0.012 & 0.291 & 0.011 & 1.20 & 2.00 & & & & \\
\hline
\end{tabular}



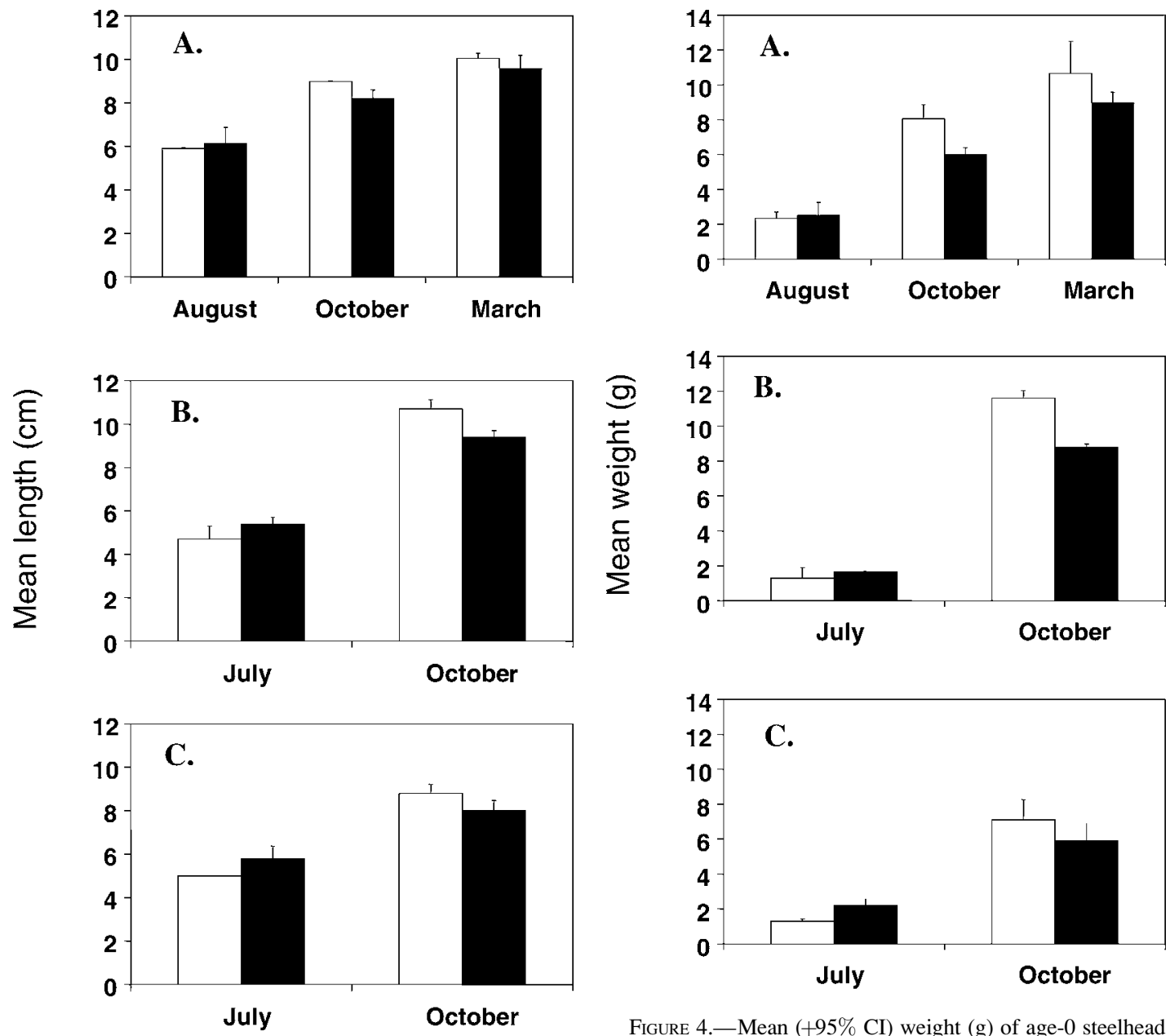

Figure 3.-Mean $(+95 \% \mathrm{CI})$ total length (TL, cm) of age-0 steelhead parr in the Muskegon River (white bars) and Bigelow Creek (black bars), Michigan: (A) August and October 1998 and March 1999; (B) July and October 2000; and (C) July and October 2001. Number of parr measured for TL in the Muskegon River was 855 in August 1998; 182 in October 1998; 63 in March 1999; 742 in July 2000; 109 in October 2000; 1,243 in July 2001; and 11 in October 2001. In Bigelow Creek, the number measured ranged from 25 to 33 fish/season for each year.

Salmon eggs comprised the majority (93\% wet weight) of the prey items for parr in Bigelow Creek in October 1998 ( $N=10$ nonempty stomachs) (Table 6). High numbers of spawning adult Chinook salmon were observed during this sampling period. In May 1999, hydropsychids, plecopterans, and amphipods were the primary prey for steelhead parr in Bigelow Creek $(N=$ 11 nonempty stomachs) (Table 6). No diet data were collected for parr during August in Bigelow Creek.

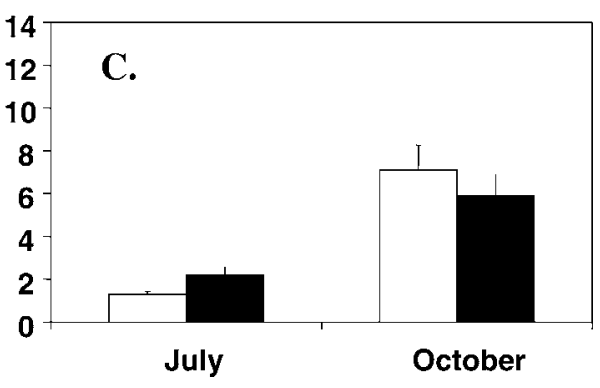

FIGURE 4.-Mean ( $+95 \% \mathrm{CI})$ weight $(\mathrm{g})$ of age-0 steelhead parr in the Muskegon River (white bars) and Bigelow Creek (black bars), Michigan: (A) August and October 1998 and March 1999; (B) July and October 2000; and (C) July and October 2001. See Figure 3 (caption) for sample sizes.

\section{Ration}

Average daily ration of parr was higher in the Muskegon River than in Bigelow Creek. Steelhead consumed an average $11.3 \pm 0.3 \%$ of body weight (BW) per day in the Muskegon River compared with $8.3 \pm 0.2 \% \mathrm{BW} / \mathrm{d}$ in Bigelow Creek. Parr achieved roughly $31 \%$ of $C_{\max }$ in each habitat.

\section{Environmental Effects on Steelhead Densities and Vital Rates}

River temperature was significantly correlated with steelhead parr survival, density, production, and consumption. Average July temperature was negatively correlated with parr density in summer $\left(P<0.01, r_{s}=\right.$ $-0.95, n=6)$ and fall $\left(P<0.01, r_{s}=-0.89, n=6\right)$. 
TABLE 6.-Prey items (\% wet weight of gut contents) of age-0 steelhead parr in the Muskegon River and Bigelow Creek, Michigan, 1998-1999 ( $N=$ number of nonempty stomachs examined for that time period). Other Trichoptera includes all trichopterans except Hydropsychidae. Bythotrephes is B. cederstroemi. Other includes the weight (\%) of unidentified taxa.

\begin{tabular}{|c|c|c|c|c|c|}
\hline \multirow[b]{2}{*}{ Taxon } & \multicolumn{3}{|c|}{ Muskegon River } & \multicolumn{2}{|c|}{ Bigelow Creek } \\
\hline & Aug $(N=49)$ & Oct $(N=33)$ & May $(N=44)$ & Oct $(N=10)$ & May $(N=11)$ \\
\hline Hydropsychidae & 17.3 & 58.2 & 26.6 & 0.9 & 34.5 \\
\hline Other Trichoptera & 9.3 & 5.5 & 16.1 & 1.3 & 12.4 \\
\hline Ephemeroptera & 4.4 & 0.5 & 21.4 & 0.1 & 8.5 \\
\hline Diptera & 2.9 & 8.0 & 22.1 & & 2.5 \\
\hline Coleoptera & 3.8 & & 2.1 & & 1.4 \\
\hline Plecoptera & 0.7 & & & & 18.8 \\
\hline Salmon eggs & & 18.5 & & 93.0 & \\
\hline Odonata & & & & & 2.9 \\
\hline Hemiptera & 5.5 & 0.1 & & & \\
\hline Amphipoda & 41.8 & 0.5 & 6.7 & 0.8 & 14.0 \\
\hline Cladocera & 7.4 & 3.8 & 0.3 & & \\
\hline Bythotrephes & 1.8 & 0.7 & & & \\
\hline Other & 5.1 & 4.8 & 4.7 & 3.9 & 5.0 \\
\hline
\end{tabular}

July temperature also was positively correlated with instantaneous daily mortality rate $\left(P<0.05, r_{s}=0.84\right.$, $n=6)$ and negatively correlated with the $G: Z$ ratio $(P$ $\left.<0.05, r_{s}=-0.89, n=6\right)$ and the Allen (1971) production estimate $\left(P<0.001, r_{s}=-0.99, n=6\right)$. There was no significant relationship between average July temperature and instantaneous growth rate of parr, consumption rate, start weight, end weight, or $p\left(C_{\max }\right)$. Cumulative discharge from the Muskegon River during mid-March-June was positively correlated with start weight $\left(P<0.001, r_{s}=0.99, n=3\right)$ and negatively correlated with production $\left(P<0.001, r_{s}=-0.99, n=\right.$ 3), $p\left(C_{\max }\right)\left(P<0.001, r_{s}=-0.99, n=3\right)$, and end weight $\left(P<0.001, r_{s}=-0.99, n=3\right)$. There was no significant correlation between spring cumulative discharge and summer or fall density, growth, or mortality of steelhead parr.

Summer density of steelhead parr was significantly correlated with steelhead production and consumption but not with other vital rates. Summer parr density was positively correlated with production $\left(P<0.01, r_{s}=\right.$
$0.94, n=6)$, negatively correlated with consumption ( $P$ $<0.05, r_{s}=-0.83, n=6$ ), and (in Bigelow Creek only) positively correlated with $p\left(C_{\max }\right)\left(P>0.01, r_{s}=\right.$ $0.99, n=3)$. There was no significant correlation between parr density in summer and growth rate, mortality rate, $G: Z$ ratio, $p\left(C_{\max }\right)$, or parr weight in fall. There was no significant correlation between instantaneous growth rate and mortality rate of steelhead parr.

Most observed relationships between environmental factors and juvenile steelhead density, vital rates, and production in the Muskegon River watershed also were observed when additional data from other Great Lakes tributaries were included (Table 7). Mean July temperature was negatively correlated with steelhead production from summer to fall $\left(P<0.001, r_{s}=-0.93\right.$, $n=8$ ). Mean July temperature also was positively correlated with instantaneous mortality rate of parr from summer to fall $\left(P<0.05, r_{s}=0.55, n=14\right)$ but not with parr growth or $G: Z$ ratio. There was no significant relationship between July parr density and growth rate, mortality rate, production, or $G: Z$ ratio

TABLE 7.-Nonparametric Spearman's rank correlation coefficients among variables affecting age-0 steelhead parr in Lake Michigan tributaries $(* p<0.05$; $* * p<0.01 ; * * p<0.001)$. Data are from Carl (1983), Seelbach (1993), Newcomb and Coon (1997), Woldt and Rutherford (2002), and E. Rutherford (unpublished data). Variables were: summer and fall parr density (fish/ ha), mean water temperature in July $\left({ }^{\circ} \mathrm{C}\right.$; Jul temp), cumulative spring discharge $\left(\mathrm{m}^{3} / \mathrm{s}\right.$; Mar $\left.15-J u n ~ 30\right)$, production $\left(\mathrm{g} / \mathrm{m}^{2}\right)$, instantaneous daily rate of growth in weight $(G)$, and instantaneous daily mortality rate $(Z)$.

\begin{tabular}{lccccccc}
\hline \multicolumn{1}{c}{ Variable } & $\begin{array}{c}\text { Fall } \\
\text { density }\end{array}$ & Production & $G: Z$ & $Z$ & $G$ & Jul temp & $\begin{array}{c}\text { Spring } \\
\text { discharge }\end{array}$ \\
\hline Summer density & 0.36 & 0.69 & -0.03 & 0.28 & -0.01 & $-0.61^{*}$ & 0.27 \\
Fall density & & $0.81^{*}$ & $0.78^{* *}$ & $-0.79 * * *$ & -0.19 & $-0.71^{* *}$ & $-0.74 * *$ \\
Production & & & 0.69 & -0.53 & -0.25 & $-0.93^{* * *}$ & $-0.99 * * *$ \\
$G: Z$ & & & & $-0.96^{* * *}$ & $-0.60^{*}$ & -0.52 & -0.64 \\
$Z$ & & & & & $0.69^{* *}$ & $0.55^{*}$ & 0.55 \\
$G$ & & & & & 0.48 & 0.49 \\
Jul temp & & & & & & & 0.27 \\
\hline
\end{tabular}


(Table 7). There was no significant relationship between cumulative river discharge during spring $\left(\mathrm{m}^{3} / \mathrm{s}\right.$, March 15 to June 30$)$ and summer parr density or instantaneous growth rate. However, contrary to earlier results from the limited sample size $(n=3)$ in the Muskegon River during 1998-2001, a stepwise regression analysis indicated that both mean July temperature and cumulative river discharge during spring were negatively related to fall steelhead density. The best-fit model was:

$$
\begin{aligned}
\text { fall density }= & 6223.73-(227.95 \times \text { July temperature }) \\
& -(0.14 \times \text { spring discharge })
\end{aligned}
$$

where $P>0.001, R^{2}=0.79$, and $n=12$. In this model, July temperature explained $55 \%$ of the total variation in fall parr density and spring discharge explained an additional $24 \%$. Instantaneous daily mortality rate was positively correlated with daily growth rate (Table $7 ; r_{s}$ $=0.69, n=7, P<0.01)$.

\section{Discussion}

Steelhead in the Muskegon River, as in other marginal thermal habitats in Great Lakes tributaries, appear to have low survival but similar growth rates relative to more optimal thermal habitats found in smaller creeks and rivers such as Bigelow Creek. Although prey densities are high and substrate composition and flows generally are favorable in the Muskegon River, production of steelhead parr appears to be limited by temperature or temperature-related factors on survival. Flow variability during early fry stages in some years also may negatively impact fry survival and parr density.

\section{Density and Mortality}

Fall densities of age- 0 steelhead parr in the Muskegon River were similar to steelhead parr densities (120-1,120 parr/ha) in the Manistee and Betsie rivers and other Lake Michigan tributaries with marginal thermal habitats (Newcomb and Coon 1997; Woldt and Rutherford 2002). In Lake Michigan tributaries with more optimal thermal habitats, such as Bigelow Creek, Little Manistee River, Platte River, Pine Creek, and Bear Creek (the latter two are tributaries of the Manistee River), fall densities of steelhead are higher, ranging from 1,500 to 2,470 fish/ ha for age-0 parr (Taube 1975; Carl 1983, Seelbach 1993; Woldt and Rutherford 2002) and from 210 to 1,480 fish/ha for yearlings (Seelbach 1993; Newcomb and Coon 1997).

The negative relationship between July temperature and fall density and survival in our study areas also has been reported in other Great Lakes tributaries. Woldt and Rutherford (2002) estimated daily mortality rates of 0.07 for age- 0 parr in the Manistee River, a large impounded Lake Michigan tributary where July water temperatures typically exceed $20^{\circ} \mathrm{C}$, and 0.002 in the Little Manistee River, a smaller tributary with cooler summer temperatures below $18^{\circ} \mathrm{C}$. In the Betsie River, a tributary of Lake Michigan, Newcomb and Coon (1997) found that instantaneous daily mortality rates of age-0 steelhead parr during July-October were positively correlated with maximum summer temperature and varied from 0.002 to 0.040. In two Lake Superior tributaries with cooler summer temperatures, Stauffer (1975) estimated a daily mortality rate of 0.01 for August-October.

The expanded time series available for juvenile steelhead parr in other Great Lakes tributaries suggested a negative influence of high flows during spring on steelhead survival. Negative correlations between river flow and steelhead egg and fry survival also have been observed in Pacific coast steelhead populations (Latterell et al. 1998; Fausch et al. 2001). In the Great Lakes, the flow effect probably occurs during the early fry stage, when individuals are most vulnerable to being washed out of favorable nursery areas. Compared with runoff-dominated rivers in Lake Superior and the Pacific coast, many Lake Michigan tributaries are hydrologically stable, low-gradient streams with high groundwater inputs (Seelbach 1993). However, extreme floods apparently can influence early life survival of Great Lakes steelhead during some years. We estimated, using Close and Anderson's (1997) data, that daily mortality of age- 0 steelhead varied from 0.02 to 0.05 (mean $Z=0.03$ ) in four western Lake Superior streams. Survival was positively related to substrate size and negatively related to cumulative discharge during June-July, when steelhead are in the early fry stage (Close and Anderson 1997). Newcomb and Coon (1997) found a negative relationship between cumulative May-June river discharge and July density of age- 0 steelhead in the Betsie River.

Estimates of natural smolt production of steelhead from the Muskegon River support our findings of low parr density and survival. The Muskegon River, like many other Lake Michigan tributaries, is heavily stocked with steelhead. Lakewide, approximately $30 \%$ of the total steelhead population is wild (Rand et al. 1993). Studies of adult steelhead returning to spawn in the Muskegon River have shown that only $10 \%$ of adults are wild or naturally produced (Swank 2005). Mark-recapture studies indicate that recruitment of wild steelhead smolts from the Muskegon River is low, less than 10,000 smolts or 96 smolts/ha, most of which probably originate in Bigelow Creek or other small tributaries (E.S.R., unpublished data). Estimated 
annual recruitment of wild smolts from the Little Manistee River, a smaller Lake Michigan tributary with a similar-sized nursery area, is nearly fourfold higher, ranging from 16,000 to 84,000 smolts and averaging 35,000 smolts, or 360 smolts/ha (Seelbach 1993).

Stressful high summer temperatures appeared to be the dominant factor influencing survival of steelhead parr in the Muskegon River. Most production of parr was lost early in summer when temperatures exceeded $21^{\circ} \mathrm{C}$. Laboratory studies indicate that survival of age- 0 steelhead parr declines dramatically at temperatures exceeding $20^{\circ} \mathrm{C}$ (Hokanson et al. 1977). Woldt and Rutherford (2002) hypothesized that the high mortality of steelhead parr during summer in the Manistee River was caused by constant high temperatures $\left(>20^{\circ} \mathrm{C}\right)$ to which parr are subjected. Croton Dam on the Muskegon River and Tippy Dam on the Manistee River (Woldt and Rutherford 2002) are top-draw dams. This epilimnial water is usually the warmest water in the reservoir during summer, and therefore contributes warm water to the tailrace and steelhead nursery area below the dam. Another consequence of a top-draw dam is that water temperatures below the dam are relatively constant, providing no thermal relief for the salmonids below the dam (Woldt and Rutherford 2002). Mean July temperatures would have to be substantially lower $\left(<19^{\circ} \mathrm{C}\right)$ to improve survival and fall density by any significant amount.

The warm summer temperatures in the Muskegon River also may indirectly increase mortality of steelhead parr through predation by warmwater predators. The Muskegon River supports abundant populations of smallmouth bass Micropterus dolomieu and walleyes Sander vitreus, both potential warmwater predators of steelhead parr (O'Neal 1997). The main predators occurring in Bigelow Creek are brown trout and older rainbow trout.

\section{Mortality, Growth, and Ration}

The positive correlation between instantaneous growth rate and mortality rate of steelhead parr in this study has also been reported for early life stages of many fish species (Houde 1997). Individuals with higher consumption and growth rates may increase metabolic rates and activity rates, thereby increasing vulnerability to predators (Metcalf and Fraser 1997; Anholt and Werner 1998; Mangel 2001). Factors, such as temperature, that can influence consumption and growth of parr also may increase predator consumption rates. Although summer temperature was not correlated with observed patterns of growth in the Muskegon River and Bigelow Creek, growth of steelhead parr was slightly faster in the Muskegon River, despite a stressfully high temperature regime. The mean monthly temperatures during summer in the Muskegon River were higher than the optimum temperature range (15$17^{\circ} \mathrm{C}$ ) for age-0 rainbow trout growth (Hokanson et al. 1977). The bioenergetics analysis indicated that parr in the Muskegon River had to consume, on average, an $84 \%$ higher daily ration than parr in Bigelow Creek to achieve similar growth rates from August to October. In contrast, temperatures in Bigelow Creek during the same period were much closer to the optimum temperature range, and parr could consume less food to achieve similar growth. Fall sizes of age- 0 parr in both rivers were comparable to sizes observed in other Great Lakes tributaries (Stauffer 1975; Taube 1975, Johnson 1980; Gordon and MacCrimmon 1982; Carl 1983; Seelbach 1993; Woldt and Rutherford 2002).

Studies of daily ration of stream rainbow trout indicate that temperature and food availability can regulate consumption in summer. Railsback and Rose (1999) used a bioenergetics model to estimate $p\left(C_{\max }\right)$ ranging from 0.24 to 0.40 for yearling rainbow trout during summer in California, which compare favorably with consumption rates in this study. They found that variation in $p\left(C_{\max }\right)$ among streams was more related to food availability than to average summer temperatures, which were below stressful levels (range of mean temperatures $=14.7-19.3^{\circ} \mathrm{C}$ ). Cada et al. (1987) suggested that low summer growth rates and condition of rainbow trout in Appalachian streams were related to low food availability and consumption and high metabolic costs.

Estimates of invertebrate prey biomass indicate that prey densities were sufficient to support high parr growth rates in both rivers. In a related study, Godby (2000) examined the invertebrate prey base in each of these rivers and reported high densities of invertebrate prey of approximately 30,000 chironomid larvae $/ \mathrm{m}^{2}$ and 5,000 hydropsychid caddisflies $/ \mathrm{m}^{2}$, which were common in the benthos and in the diet of steelhead parr. These prey densities are similar to macroinvertebrate prey densities (mean chironomid density = 15,000 individuals $/ \mathrm{m}^{2}$; mean caddisfly [Protoptila] density $=3,100$ individuals $/ \mathrm{m}^{2}$ ) supporting high densities of age-0 brook trout Salvelinus fontinalis (4,500 fish/ha) in 12 small Michigan streams (Hinz and Wiley 1998). Both the Muskegon River and Bigelow Creek have abundant cobble-gravel habitats that support large populations of invertebrate prey and attract dense concentrations of spawning salmon. Diets of age- 0 steelhead parr were composed largely of the dominant taxa found in the benthos. In October, salmon eggs became an important component of the steelhead parr diet during the Chinook salmon spawning run, and comprised $19 \%$ of the diet in the 
Muskegon River and $93 \%$ of the diet in Bigelow Creek.

Although sample sizes of steelhead parr diets were limited at times in Bigelow Creek and the Muskegon River, we are confident that they are representative of wild trout diets. Merna (1986) reported that salmon eggs comprised an average $30-40 \%$ of the total ration by weight for yearling and older rainbow trout and brown trout ( $n=25$ fish) in Bigelow Creek during fall of 1977 and 1978. Trichoptera, Diptera, and Ephemeroptera were the dominant prey taxa in trout diets during spring and summer. From 2003 to 2005, we conducted additional diet sampling of age-0 steelhead from Bigelow Creek and found similar diet compositions of primarily Hydropsychidae and Chironomidae in summer ( $n=8$ empty stomachs) and spring ( $n=10$ nonempty stomachs) and a mixture of macroinvertebrates and salmon eggs in fall $(n=45$ nonempty stomachs) (E.S.R., unpublished data). Our estimates of steelhead diets in the Muskegon River in spring may have been biased by including some hatchery fish, but other studies suggest that hatchery and wild fish forage for similar items after a short acclimation period (e.g., Johnson 1981; Johnson et al. 1996). Previous research on rainbow trout foraging indicates that they eat a variety of prey items. Yearling rainbow trout in the Platte River, Michigan, ate large quantities of Brachycentridae, Simuliidae, and Ephemeroptera (Wagner 1975). Steelhead parr in a Lake Ontario tributary fed primarily on benthic invertebrates, especially Ephemeroptera and Chironomidae (Johnson and Ringler 1980). Diet of steelhead parr in a Lake Superior tributary changed from mainly benthic insects to terrestrial drift when the fish exceeded $7 \mathrm{~cm}$ in length (Kwain 1983). Data from studies of western rivers show that juvenile rainbow trout feed on terrestrial and aquatic insects from the drift and benthos (Allan 1983; Johnson 1985).

\section{Production}

The estimated average production of 0.4 and $2.0 \mathrm{~g} /$ $\mathrm{m}^{2}$ of age-0 steelhead parr from the Muskegon River and Bigelow Creek were similar to estimates for steelhead production in other Great Lakes and Pacific coast tributaries. Using Woldt and Rutherford's (2002) data, we calculated that summer-fall production of age0 steelhead was $1.8 \mathrm{~g} / \mathrm{m}^{2}$ in the Manistee River and 0.9 $\mathrm{g} / \mathrm{m}^{2}$ in the Little Manistee River. Values for age-0 steelhead production estimated in other Great Lakes tributaries range from 0.6 to $2.4 \mathrm{~g} / \mathrm{m}^{2}$ (Hunneksala 1973; Stauffer 1975; Johnson 1980; Wisniewski 1990). In Idaho streams, age-0 steelhead parr production ranged from 0.1 to $2.6 \mathrm{~g} / \mathrm{m}^{2}$ (estimated from Goodnight and Bjornn 1971).
The lack of a relationship between steelhead density and growth indicates that carrying capacity was not exceeded for age- 0 parr in the Muskegon River or Bigelow Creek. Density has long been identified as a factor influencing territory size, body size, and survival of stream salmonids (Chapman 1966; Allen 1969; Grant and Kramer 1990; Elliott 1993; Dunham and Vinyard 1997). Salmonids use territories primarily for feeding, so density of fish in a space during the growing season depends upon food availability (Dill et al. 1981; Marschall and Crowder 1995). When food is limited, a given area of stream may support fewer individuals in a cohort of large fish than in a cohort of small fish. Marschall and Crowder (1995) developed a relationship between maximum salmonid density and body size to estimate the lowest parr density at which parr size or parr survival is limited. The model was density $\left(\mathrm{parr} / \mathrm{m}^{2}\right)=587 \times \mathrm{TL}^{-2.57}$. Using Marschall and Crowder's (1995) model, we estimated that at the sizes observed for steelhead parr, observed densities were 11-37-fold lower than densities predicted for the Muskegon River and 7-10-fold lower than those predicted for Bigelow Creek. These results suggest that food and space did not limit survival or size of steelhead parr in these streams.

Our estimates of parr density and survival in the Muskegon River may be biased if juvenile steelhead parr actively migrate out of the study area before the fall survey in October. In other rivers, steelhead parr are known to migrate downstream or seek shelter in tributary creeks during late fall to survive overwinter (e.g., Bjornn 1971; Leider et al. 1986; Mitro and Zale 2002), or they may move from tributary creeks to main-stem habitats (Johnson and Kucera 1985; Sheppard and Johnson 1985). In these studies, parr movements were most pronounced as average daily temperatures cooled below $10^{\circ} \mathrm{C}$ and when cover was not available. We believe that parr movement out of the Muskegon River study area was unlikely to occur before fall because temperatures rarely fell below $10^{\circ} \mathrm{C}$ before or during fall surveys and because there are abundant groundwater seeps, fallen logs, cobble, and boulders in the study area that serve as shelter for overwintering parr. Woldt and Rutherford (2002) found that movement of marked age-0 steelhead parr was limited in the main stem of the Manistee River during summer and fall, and parr were found within 1 $\mathrm{km}$ of their release site. However, movement between tributaries and main-stem habitats may have occurred after fall and potentially biased overwinter survival rates. Our steelhead parr densities changed from being 20-fold higher in Bigelow Creek than in the Muskegon River in fall to 10-fold higher in spring, suggesting that parr either experienced higher overwinter mortality 
rates in Bigelow Creek or moved from Bigelow Creek to the Muskegon River. Other studies have documented such movement of parr from tributaries to main-stem habitats in late fall and winter (Johnson 1985; Johnson and Kucera 1985; Woldt and Rutherford 2002).

\section{Management Implications}

Our study indicates that high summer temperatures may limit nursery habitat for steelhead in the mainstem Muskegon River but that small tributary creeks like Bigelow Creek serve as important refugia. Observations from other large Lake Michigan watersheds (Betsie and Manistee rivers) also highlight the importance of thermal refugia in small tributary creeks (Newcomb and Coon 1997; Woldt and Rutherford 2002). Our results may be useful for managers desiring to protect sensitive nursery areas from development or degradation. Because stream size is often positively correlated with temperature and because large rivers may have significant thermal mass, it may not be feasible to lower river temperatures sufficiently in the main stem to provide good habitat throughout the year for steelhead parr. However, in some impounded rivers manipulation of tailrace temperatures through piping cold water from the bottom of the reservoir above the nursery area may improve survival and production of steelhead parr, thereby lessening the need for hatchery supplementation.

\section{Acknowledgments}

We thank David Swank, Brad Horne, Deborah Schaner, Solomon David, and Jeremy Price for able assistance with fieldwork, and the Michigan Department of Natural Resources (MDNR) Fisheries Division for vehicles and equipment. We acknowledge funding support from the Michigan Habitat Improvement Fund, MDNR Fisheries Division, Michigan Sea Grant (Number R/GLF-48), and the Great Lakes Fisheries Trust. Reference to trade names does not imply endorsement by the U.S. Government.

\section{References}

Allan, J. D. 1983. Predator-prey relationships in streams Pages 191-229 in G. W. Minshaw and J. R. Barnes, editors. Stream ecology: application and testing of general ecological theory. Plenum, New York.

Allen, K. R. 1969. Limitations on production in salmonid populations in streams. Pages 3-18 in Symposium on salmon and trout in streams. Institute of Fisheries, University of British Columbia, Vancouver.

Allen, K. R. 1971. Relation between production and biomass. Journal of the Fisheries Research Board of Canada 28:1573-1581.

Bjornn, T. C. 1971. Trout and salmon movements in two Idaho streams as related to temperature, food, stream flow, cover, and population density. Transactions of the American Fisheries Society 100:423-438.

Cada, G. F., J. M. Loar, and M. J. Sale. 1987. Evidence of food limitation of rainbow and brown trout in southern Appalachian soft-water streams. Transactions of the American Fisheries Society 116:692-702.

Carl, L. M. 1982. Natural reproduction of coho salmon and Chinook salmon in some Michigan streams. North American Journal of Fisheries Management 4:375-380.

Carl, L. M. 1983. Density, growth, and change in density of coho salmon and rainbow trout in three Lake Michigan tributaries. Canadian Journal of Zoology 61:1120-1127.

Chapman, D. W. 1966. Food and space as regulators of salmonid populations in streams. American Naturalist 100:345-357.

Close, T. L., and C. S. Anderson. 1997. Factors limiting juvenile steelhead survival in streams tributary to waters of Lake Superior. Minnesota Department of Natural Resources Division of Fish and Wildlife Investigational Report 462.

Dill, L. M., R. C. Ydenberg, and A. H. G. Fraser. 1981. Food abundance and territory size in juvenile coho salmon (Oncorhynchus kisutch). Canadian Journal of Zoology 59:1801-1809.

Dunham, J. B., and G. L. Vinyard. 1997. Relationships between body mass, population density, and the selfthinning rule in stream-living salmonids. Canadian Journal of Fisheries and Aquatic Sciences 54:1025-1030.

Elliott, J. M. 1993. Self-thinning rule applied to juvenile sea trout, Salmo trutta. Journal of Animal Ecology 62:371379.

Everhart, W. H., and W. D. Youngs. 1981. Principles of fishery science. Comstock Publishing, Ithaca, New York.

Fausch, K. D., Y. Taniguchi, S. Nakano, G. D. Grossman, and C. R. Townsend. 2001. Flood disturbance regimes influence rainbow trout invasion success among five holarctic regions. Ecological Applications 11:14381455 .

Godby, N. A., Jr. 2000. Growth, diet, and prey availability for juvenile steelhead in Muskegon River, Michigan. Master's thesis. University of Michigan, Ann Arbor.

Goodnight, W. H., and T. C. Bjornn. 1971. Fish production in two Idaho streams. Transactions of the American Fisheries Society 100:769-780.

Gordon, D. J., and H. R. MacCrimmon. 1982. Juvenile salmonid production in a Lake Erie nursery stream. Journal of Fish Biology 21:455-473.

Grant, J. W. A., and D. L. Kramer. 1990. Territory size as a predictor of the upper limit to population density of juvenile salmonids in streams. Canadian Journal of Fisheries and Aquatic Sciences 47:1724-1737.

Hanson, P. C., T. B. Johnson, J. F. Kitchell, and D. E. Schindler. 1997. Fish bioenergetics 3.0 University of Wisconsin Sea Grant Institute, Report WISCU-T-97001, Madison.

Hinz, L. C., Jr., and M. J. Wiley. 1998. Growth and production of juvenile trout in Michigan streams: influence of potential ration and temperature. Michigan Department of Natural Resources, Fisheries Research Report 2042, Ann Arbor.

Hokanson, K. E., C. F. Kleiner, and T. W. Thorslund. 1977. Effects of constant temperatures and diel temperature 
fluctuations on specific growth and mortality rates and yield of juvenile rainbow trout. Journal of the Fisheries Research Board of Canada 34:639-648.

Houde, E. D. 1997. Patterns and consequences of selective processes in teleost early life histories. Pages 173-196 in R. C. Chambers and E. A. Trippel, editors. Early life history and recruitment in fish populations. Chapman and Hall, New York.

Hunneksala, P. R. 1973. Food interrelationships of the mottled sculpin, Cottus bairdi, and juveniles of the rainbow trout, Salmo gairdneri, in a tributary of Lake Superior. Master's thesis. University of Michigan, Ann Arbor.

Ichthyological Associates. 1991. Habitat mapping report for the Croton Project, FERC Project No. 2468, Muskegon River, Michigan. Ichthyological Associates, New York.

Johnson, J. H. 1980. Production and growth of subyearling coho salmon, Oncorhynchus kisutch, Chinook salmon, Oncorhynchus tshawytscha, and steelhead, Salmo gairdneri, in Orwell Brook, tributary of Salmon River, New York. U.S. National Marine Fisheries Service Fishery Bulletin 78:549-554.

Johnson, J. H. 1981. Food interrelationships of coexisting brook trout, brown trout and yearling rainbow trout in tributaries of the Salmon River, New York. New York Fish and Game Journal 28:88-99.

Johnson, J. H. 1985. Comparative diets of Paiute sculpin, speckled dace, and subyearling steelhead trout in tributaries of the Clearwater River, Idaho. Northwest Science 59:1-9.

Johnson, J. H., and P. A. Kucera. 1985. Summer-autumn utilization of subyearling steelhead trout in tributaries of the Clearwater River, Idaho. Canadian Journal of Zoology 63:2283-2290.

Johnson, J. H., J. F. McKeon, and D. S. Dropkin. 1996. Comparative diets of hatchery and wild Atlantic salmon smolts in the Merrimack River. North American Journal of Fisheries Management 16:440-444.

Johnson, J. H., and N. H. Ringler. 1980. Diets of juvenile coho salmon (Oncorhynchus kisutch) and steelhead trout (Salmo gairdneri) relative to prey availability. Canadian Journal of Zoology 58:553-558.

Johnston, T. A., and R. A. Cunjak. 1999. Dry mass-length relationships for benthic insects: a review with new data from Catamaran Brook, New Brunswick, Canada. Freshwater Biology 41:653-674.

Kwain, W. 1983. Downstream migration, population size, and feeding of juvenile rainbow trout. Journal of Great Lakes Research 9:52-59.

Latterell, J. J., K. D. Fausch, C. Gowan, and S. C. Riley. 1998. Relationship of trout recruitment to snowmelt runoff flows and adult trout abundance in six Colorado mountain streams. Rivers 6:240-250.

Leider, S. A., M. W. Chilcote, and J. J. Loch. 1986. Movement and survival of presmolt steelhead in a tributary and the main stem of a Washington river. North American Journal of Fisheries Management 6:526-531.

Marschall, E. A., and L. B. Crowder. 1995. Density-dependent survival as a function of size in juvenile salmonids in streams. Canadian Journal of Fisheries and Aquatic Sciences 52:136-140.

Merna, J. W. 1986. Contamination of stream fishes with chlorinated hydrocarbons from eggs of Great Lakes salmon. Transactions of the American Fisheries Society 115:69-74.

Mitro, M. G., and A. V. Zale. 2002. Seasonal survival, movement, and habitat use of age- 0 rainbow trout in the Henrys Fork of the Snake River, Idaho. Transactions of the American Fisheries Society 131:271-286.

Newcomb, T. J., and T. G. Coon. 1997. Environmental variability and survival of steelhead parr in a thermally diverse watershed. Michigan Department of Natural Resources, Fisheries Research Report 2046, Ann Arbor.

O’Neal, R. P. 1997. Muskegon River Watershed Assessment. Michigan Department of Natural Resources, Fisheries Division, Lansing.

Petts, G. E. 1984. Impounded rivers. Wiley, New York.

Pitcher, T. J., and P. J. B. Hart. 1996. Fisheries ecology. Chapman and Hall, London.

Railsback, S. F., and K. A. Rose. 1999. Bioenergetics modeling of stream trout growth: temperature and food consumption effects. Transactions of the American Fisheries Society 128:241-256.

Rand, P. S., D. J. Stewart, P. W. Seelbach, M. L. Jones, and L. R. Wedge. 1993. Modeling steelhead population energetics in Lakes Michigan and Ontario. Transactions of the American Fisheries Society 122:977-1001.

Scheaffer, R. L., W. Mendenhall III, and R. L. Ott. 1996. Elementary survey sampling, 5th edition. Wadsworth, Belmont, California.

Seelbach, P. W. 1987. Effect of winter severity on steelhead smolt yield in Michigan: an example of the importance of environmental factors in determining smolt yield. Pages 441-450 in M. J. Dadswell, R. J. Klauda, C. M. Moffitt, R. L. Saunders, R. A. Rulifson, and J. E. Cooper, editors. Common strategies of anadromous and catadromous fishes. American Fisheries Society, Symposium 1, Bethesda, Maryland.

Seelbach, P. W. 1993. Population biology of steelhead in a stable-flow, low-gradient tributary of Lake Michigan. Transactions of the American Fisheries Society 122: 179-198.

Sheppard, J. D., and J. H. Johnson. 1985. Probability-of-use for depth, velocity, and substrate by subyearling coho salmon and steelhead trout in Lake Ontario tributary streams. North American Journal of Fisheries Management 5:391-403.

Stauffer, T. M. 1975. Population characteristics and summerto-autumn survival of juvenile rainbow trout and coho salmon in two Lake Superior tributaries, 1969-1972. Michigan Department of Natural Resources, Fisheries Research Report 1825, Ann Arbor.

Swank, D. R. 2005. Life history variation and management of wild Great Lakes steelhead populations. Doctoral dissertation. University of Michigan, Ann Arbor.

Talheim, D. R. 1987. Economics of Great Lakes fisheries: a 1985 assessment. Special Economic Report. Great Lakes Fishery Commission, Ann Arbor, Michigan.

Taube, C. M. 1975. Abundance, growth, biomass, and interrelationship of trout and coho salmon in the Platte River. Michigan Department of Natural Resources, Fisheries Research Report 1830, Ann Arbor.

Wagner, W. C. 1975. Food habits of coexisting juvenile coho 
salmon, brown trout, and rainbow trout in Platte River, 1967 and 1972. Michigan Department of Natural Resources, Fisheries Research Report 1831, Ann Arbor.

Wisniewski, S. J. 1990. Secondary production of salmonids in tributaries of the Salmon River, New York. Master's thesis. State University of New York, College of Environmental Science and Forestry, Syracuse.

Woldt, A. P., and E. S. Rutherford. 2002. Production of juvenile steelhead in two central Lake Michigan tributaries. Michigan Department of Natural Resources, Fisheries Research Report 2060, Ann Arbor. 